\title{
Pseudomonas oleovorans Endocarditis in a Child: The First Reported Case
}

\author{
Pseudomonas oleovorans Endokarditi Olan Çocuk Hasta: \\ Literatürdeki Illk Olgu
}

\author{
Kamile Arıkan', Hayrettin Hakan Aykan², Ateş Kara' ${ }^{1}$ Ali Bülent Cengiz ${ }^{1}$ \\ ${ }^{1}$ Department of Pediatrics, Hacettepe University School of Medicine, Ankara, Turkey \\ ${ }^{2}$ Department of Pediatric Cardiology, Hacettepe University School of Medicine, Ankara, Turkey
}

Cite this article as: Arıkan K, Aykan HH, Kara A, Cengiz AB. Pseudomonas oleovorans endocarditis in a child: the first reported case. J Pediatr Inf 2018;12(3):e115-e117

\begin{abstract}
Infectious endocarditis (IE) is a rare, but potentially fatal disease in pediatric patients. Most patients have underlying hemodynamic problems that predispose them to the risks of IE. Modified Duke criteria are commonly used for clinical diagnosis of IE. Though Streptococcus viridans and Staphylococcus aureus are the main pathogens of the disease, other pathogens have also been isolated. Herein we describe the first reported case of infective endocarditis caused by Pseudomonas oleovorans a girl with operated ventricular septal defect (VSD).
\end{abstract}

Keywords: Pseudomonas oleovorans, congenital heart defect, Pseudomonas spp., infective endocarditis

\section{Introduction}

Pseudomonas and related genera are aerobic, motile, nonspore-forming, nonfermentative, gram-negative bacilli that live in soil, in water and on plants and animals. Most organisms of these genera are ubiquitous and rarely pathogenic in humans. Although the Pseudomonas spp. may produce disease in any individual, they are usually opportunists that more commonly cause disease in patients with burns, cystic fibrosis, malignant diseases and immunodeficiency. While most infections
Öz

Enfektif endokardit (EE) çocuklarda nadir görülen ancak mortalitesi yüksek bir hastalıktır. Çoğu hastanın EE için risk oluşturan hemodinamik bozuklukları bulunmaktadır. EE klinik tanısı için çoğunlukla modifiye Duke kriterleri kullanılmaktadır. Streptococcus viridans ve Staphylococcus aureus en sık izole edilen etkenler olmakla birlikte, etyolojide farklı mikroorganizmalar da saptanabilmektedir. Burada ventriküler septal defekt nedeniyle opere olan bir kız hastada etken olarak Pseudomoans oleovorans'ın saptandığı literatürdeki ilk EE'li olgu sunulmaktadır.

Anahtar Terimler: Pseudomonas oleovorans, konjenital kalp hastalığı, Pseudomonas spp., enfektif endokardit

are caused by Pseudomonas aeruginosa, other Pseudomonas spp. may also give rise to severe infections less frequently. Infective endocarditis (IE) is a bacterial or fungal infection of the endocardium and/or heart valves that damages the endocardial tissue and/or valves. Pseudomonas oleovorans has been reported as a pathogen in sepsis, peritonitis, meningitis but it has not been reported as a pathogen in infective endocarditis (IE) (1-3). Herein we describe a case of infective endocarditis caused by $P$. oleovorans in a girl operated for ventricular septal defect (VSD). 


\section{Case Report}

A 14 year-old female with a history of operation for VSD at 6 years old of age and insertion of pacemaker to the right atrium and ventricle at 7 years old of age due to antrioventricular block, presented with fever persisting for 10 days which started after change of pacemaker. Due to persistant fever and increase in blood C-reactive protein (CRP), she had been hospitalised at an other center for 20 days. She was admitted to our center, because of fever persisting for 1 month, fatigue and chest pain. On admission, she was mildly ill appearing. Physical examination revealed a grade II-III/VI systolic ejection murmur. Laboratory evaluation noted bicytopenia (hemoglobin: 9.5 $\mathrm{g} / \mathrm{dL}$, thrombocyte count: $127 \times 10^{3} / \mu \mathrm{L}$, leucocyte count: 5.9 $\times 10^{3} / \mu \mathrm{L}$ ), elevated erythrocyte sedimentation rate: $26 \mathrm{~mm} / \mathrm{h}$ (0-20), increased CRP: $7.8 \mathrm{mg} / \mathrm{dL}$ (0-0.8), rheumatic factor positivity: $23.7 \mathrm{IU} / \mathrm{mL}$ (0-20), normal biochemistry and serum complements $\mathrm{C} 3$ and $\mathrm{C} 4$ levels. Transthoracic echocardiography $(\mathrm{ECHO}$ ) revealed $5 \times 5 \mathrm{~mm}$ and $17 \times 4 \mathrm{~mm}$ vegetations next to tricuspid valve, at right ventricle. She was hospitalized due to infective endocarditis and sulbactam ampicillin and amikacin were started after blood cultures were taken. P. oleovorans was isolated from two of the blood cultures taken on admission. Cultured $P$. oleovorans was susceptible to amikacin, ciprofloxacin, colistin, gentamicin, imipenem, piperacillin tazobactam, but resistant to cefepime, ceftazidime and meropenem. Due to persistant fever and blood culture positivity, therapy was changed to piperacillin tazobactam plus amikacin. Blood culture was sterile at the seventh day of antibiotic treatment. She was operated at the thirteenth day of hospitalisation, infected pacemaker was extracted and residual VSD was closed. Tissue culture taken perioperatively from vegetation resulted as negative which was attributed to antibiotic therapy during blood culturing. Repeated transthoracic ECHO was obtained and there was no evidence of vegetation at the the $21^{\text {th }}$ day of therapy. After completion of 6 weeks of total antibiotic therapy, the patient was discharged and no complication was noted at control visits.

\section{Discussion}

Most children and adolescents with IE have an identifiable risk factor, and congenital heart defects (CHDs) as in our case, represent the major risk factor for IE today. CHDs are the most common birth defects worldwide, and affect approximately 1 per 100 live births (4). Survival of patients with CHDs has improved, and the population of children and adolescents with CHDs is expanding. Despite the improved survival, CHDs still represent an important cause of morbidity and mortality at young ages. A significant number of deaths occur among patients with infections. The previously reported incidence of IE in patients with CHDs is 15-140 times higher than that in the general population, and CHDs also represent an important risk factor for increased mortality and complications in patients with IE (5). A particular form of IE is an infection where bacteria adhere to the leads of transvenously coronary implanted electronic devices, such as a pacemaker. In this type of infection, adherence of the bacteria to the foreign material and a subsequent formation of biofilm are believed to be important such as in our case.

Modified Duke criteria are commonly used for clinical diagnosis of IE (6). Though Streptococcus viridans and Staphylococcus aureus are the main pathogens of the disease, other pathogens have also been isolated (7). In a systematic review of 105 studies from 36 countries and a total of 33.214 cases S. aureus was found to be the most common microorganism, being the most frequent in $54.3 \%$ of studies $(n=57)$. Viridans group streptococci (VGS), coagulase-negative staphylococci (CNS), Enterococcus spp. and Streptococcus bovis were among the most common causative agents (8). Gram-negative pathogens account for less than $10 \%$ of all cases of infective endocarditis worldwide and endocarditis due to Pseudomonas spp. is rare (9).

In a study of 19 cases that fulfilled the criteria of definite endocarditis according to the modified Duke criteria, one (5.3\%) blood culture was isolated as P. aeruginosa (10). The members of the genus Pseudomonas are known opportunistic pathogens. On the basis of $16 \mathrm{~S}$ rRNA analysis, Pseudomonas spp. have been reorganized under various groups, each with several species. $P$. oleovorans was first described by Lee and Chandler in 1941 and taxonomically, it belongs to 16S rRNA group I (P. aeruginosa group) (11). P. oleovorans is a versatile bacterium capable of carrying out industrially important biocata-lytic reactions such as oxidative assimilation of alkanes epoxidation of alkanes and fatty acids. P. oleovorans is an environmental isolate rarely detected in clinical specimens (12). Gilardi in 1972 reported the identification of this organism from many clinical specimens, but it was not considered pathogenic in any of these instances (13). Cowlishaw et al. reported the first case of $P$. oleovorans meningitis in an 8-month-old infant (1). Another case of peritoneal dialysis-associated peritonitis was reported by Hage et al (2). A case of septicemia due to $P$. oleovorans in a patient with disseminated staphylococcal infection who was on prolonged mechanical ventilation was also reported (3).

The diagnosis of IE is difficult and often made late, which highlights the need to consider the diagnosis of IE in any patient with a CHD and pacemaker, as the major risk factor for IE in our case, who presents with fever or other signs of infection. We conclude that $P$. oleovorans may be an important emerging non-P. aeruginos $a$ or an under-diagnosed pathogen 
in patients with underlying disease. It should be kept im mind that atypical and rare pathogens as in this case report can be causative agent. This report highlights the potential of unusual environmental species of Pseudomonas as opportunistic human pathogens. Microbiologists and clinicians should be aware of emerging pathogenic species of Pseudomonas, and these clinical conditions may predispose the patients to bacterial infection.

Informed Consent: Written consent was obtained from the patient's family.

Peer-review: Externally peer-reviewed.

Author Contributions: Concept - KA; Design - KA; Supervision $\mathrm{HHA}, \mathrm{AK}, \mathrm{ABC}$; Data Collection and/or Processing - KA; Analysis and/ or Interpretation - KA, HHA; Literature Review - KA; Writing - KA; Critical Review - HHA, AK, ABC.

Conflict of Interest: The authors have not reported a conflict of interest.

Financial Disclosure: No financial disclosure was declared by the authors.

\section{References}

1. Cowlishaw WA, Hughes ME, Simpson HC. Meningitis caused by an alkaliproducing Pseudomonas spp. J Clin Pathol 1976;29:1088-90.

2. Hage JE, Schoch PE, Cunha BA. Pseudomonas pseudoalcaligenes peritoneal dialysis-associated peritonitis. Perit Dial Int 2013;33:223-4.
3. Gautam L, Kaur R, Kumar S, Bansal A, Gautam V, Singh $M$, et al. Pseudomonas oleovorans sepsis in a child: the first reported case in India. Jpn J Infect Dis 2015;68:254-5.

4. Leirgul E, Fomina T, Brodwall K, Greve G, Holmstrøm H, Vollset SE, et al. Birth prevalence of congenital heart defects in Norway 1994-2009 a nationwide study. Am Heart J 2014;168:956-64.

5. Verheugt $C L$, Uiterwaal CS, van der Velde ET, Meijboom FJ, Pieper PG, Veen $G$, et al. Turning 18 with congenital heart disease: prediction of infective endocarditis based on a large population. Eur Heart J 2011;32:1926-34.

6. Durack DT, Lukes AS, Bright DK. New criteria for diagnosis of infective endocarditis: utilization of specific echocardiographic findings. Duke Endocarditis Service. Am J Med 1994;96:200-9.

7. Quagliarello V. Infective endocarditis: global, regional, and future perspectives. JAMA 2005;293:3061-2.

8. Vogkou CT, Vlachogiannis NI, Palaiodimos $L$, Kousoulis AA. The causative agents in infective endocarditis: a systematic review comprising 33,214 cases. Eur J Clin Microbiol Infect Dis 2016;35:1227-45.

9. Ambrosioni J, Hernandez-Meneses M, Tellez A, Pericàs J, Falces C, Tolosana JM, et al. The changing epidemiology of infective endocarditis in the twenty-first century. Curr Infect Dis Rep 2017;19:2.

10. Wei $C, W u K G$, Syc $L$, Chen C, Tanga R. Infectious endocarditis in pediatric patients: analysis of 19 cases presenting at a medical center. J Microbiol Immunol Infect 2010;43:430-7.

11. Lee $M$, Chandler AC. A study of the nature, growth and control of bacteria in cutting compounds. J Bacteriol 1941;41:373-86.

12. Van Beilen JB, Eggink $G$, Enequist $H$, Bos $R$, Witholt $B$. DNA sequence determination and functional characterization of the OCT-plasmidencoded alkJKL genes of Pseudomonas oleovorans. Mol Microbiol 1992; 6:3121-36.

13. Gilardi GL. Infrequently encountered Pseudomonas species causing infection in humans. Ann Intern Med 1972;77:211-5. 